\title{
Orientalismus jako paradigma moci: Antropologická perspektiva
}

\author{
Václav Soukup \\ Katedra teorie kultury (kulturologie) Filozofické fakulty Univerzity Karlovy v Praze, Celetná 20, 11000 Praha 1
}

\section{ORIENTALISM AS PARADIGM OF POWER: ANTHROPOLOGICAL PERSPECTIVE}

\begin{abstract}
The aim of the article is the theoretical analysis of historical and socio-cultural relations between Euro-american Western culture (Occident) and Eastern Islamic culture (Orient). The article described causes and consequences of acultural processes which have been running over for a long time between Orient and Occident. The main historical turning point in relations between Christian and Islamic culture was the colonial expansion of the West, resulting in military, political, and economical dominance over oriental countries. However, it was the Western science that had contributed to the imposement of Western hegemony over the East as well. Scientist's, writer's, and artist's interest in oriental cultures led even during colonial period to the birth of Orientalism as a new scientific discipline striving for description and interpretation of the Orient. As Palestinian literary critic Edward W. Said noticed, Orientalism was never objective and ideologically desinterrested science, but a discursus of power, as through scientific and literary texts it created false and stereotypical picture of Orient, which legitimized hegemony of the West. If we think over the problem of clash of civilizations from the perspective of Orientalism as a discursus of power, it is clear that it is not adequate to install equality in the area of political and economical relations to the optimalization of relations between the West and the East. No less importance is the deconstruction of cultural discursus of Orientalism, which reflects traditional colonial and postcolonial inequality.
\end{abstract}

KEY WORDS Orient; Occident; Orientalism; Discursus of Power; Culture

\begin{abstract}
ABSTRAKT Předmětem studie je teoretická analýza historických a sociokulturních vztahů mezi euroamerickou západní kulturou (Okcident) a východní islámskou kulturou (Orient). V článku jsou popsány a interpretovány příčiny a důsledky akulturačních procesů, které mezi Orientem a Okcidentem probíhají po dlouhé období. Základní historický zlom ve vztahu křestanské a islámské kultury znamenala koloniální expanze Západu ústící ve vojenskou, politickou a ekonomickou nadvládu nad zeměmi Orientu. K nastolení hegemonie Západu nad Východem však výrazně přispěla také západní věda. Zájem vědců, spisovatelů a umělců o orientální kultury vedl již v koloniálním období ke zrodu orientalismu jako nové vědní disciplíny usilující o popis a interpretaci Orientu. Jak upozornil palestinský literární kritik Edward W. Said, orientalismus nikdy nebyl objektivní a ideologicky nezaujatou vědou, ale diskurzem moci, nebot prostřednictvím vědeckých a literárních textů vytvářel zkreslený, falešný a stereotypizovaný obraz Orientu, který legitimoval nadvládu Západu. Zamyslíme-li se nad problémem střetu civilizací z perspektivy orientalismu jako diskurzu moci, je zřejmé, že k optimalizaci vztahu mezi Západem a Východem nestačí nastolit rovnoprávnost v oblasti politických a ekonomických vztahů. Neméně důležitá je dekonstrukce kulturního diskurzu orientalismu, který v sobě odráží tradiční koloniální a postkoloniální nerovnost.
\end{abstract}

KLÍČOVÁ SLOVA Orient; Okcident; orientalismus; diskurz moci; kultura

\section{ORIENT VERSUS OKCIDENT}

V dnešním stále více globalizovaném světě narůstá význam antropologie jako aplikované vědy, která umožňuje pochopit svět „těch druhých“ v kontextu různých variant potenciálních i skutečných kulturních konfliktů. Je smutné, že dějiny lidstva jsou plné válek mezi společnostmi, které sdílejí různou barvu pleti, etnickou prŕslušnost nebo odlišnou kulturu. Americký religionista Joseph Campbell (1904-1977), zabývající se komparativní mytologií, je přesvědčen, že mýty všech tradičních společností glorifikují válku vedenou ve jménu vlastní kultury (Cambell 1988). Dokonce i v Bibli v Páté knize Mojžíšově na- 
lezneme slova, která věřící vyzývají ke genocidě: „Ale ve městech těchto národì, které ti dává Hospodin, tvůj Bůh, do dědictví, nenecháš naživu naprosto nikoho. Zničís je jako klaté, Chetejce, Emorejce, Kenaance, Perizejce, Chivejce a Jebusejce, jak príkázal Hospodin, tvi̊j Bůh" (Bible 1979, 157). Pohlížímeli z této perspektivy na biblické páté přikázání „nezabiješ“, je evidentní, že se vztahuje pouze na př́slušníky vlastního kmene, zatímco teritoriální expanze založená na vybíjení „těch druhých“ je nejen povolena, ale i doporučena jako „př́íkaz Božíc.

Fatální dichotomie „my“ a „oni“ nalezla své nejostudnější vyjádření ve válečných konfliktech, jež prostupují jako krvavá černá nit lidskými dějinami od starověku až k moderní civilizaci. Je evidentní, že hra na „společného nepř́ítele“ vždy posilovala sociální integritu a solidaritu příslušníků odlišných kultur, a tento mechanismus, navzdory růstu lidského vědění a vědeckého pokroku, i na počátku třetího tisíciletí ovlivňuje osudy milionů lidí. V dobách koloniální nadvlády Západu nad ostatními zeměmi mohli Evropané, disponující absolutní mocí, bez větších problémů vnutit porobeným zemím svá pravidla. V současné době, kdy bývalé kolonie dosáhly politické samostatnosti, musí Západ, který má stále zájem na navození sociokulturních změn v jiných společnostech, o svých záměrech vyjednávat. A právě zde se odkrývá široký prostor pro uplatnění antropologických poznatků $\mathrm{v}$ praxi. Je totiž zřejmé, že interkulturní vyjednávání bude úspěšnější, když jeho účastníci budou rozumět příčinám kulturních rozdílů ve svých cílech, postojích a názorech.

Jednu z klíčových dichotomií současnosti představují kategorie Západ (Okcident) - Východ (Orient). Vojenská a kulturní konfrontace mezi křestanskou Evropou a islámskými ř́šemi trvá od doby středověku. Po kulturním a náboženském sjednocení arabských pouštních kmenů v době proroka Muhammada (570-632) Arabové zahájili rozsáhlé vojenské výboje. Výsledkem této expanze byl vznik říše velikostí srovnatelné s bývalým římským impériem. V 8.-12. století arabský chalífát zahrnoval území sahající od Himalájí přes Střední východ a severní Afriku až na Pyrenejský poloostrov. Později, prostřednictvím tureckých výbojů, pronikl vliv islámu také na celý Balkán. Vrcholné období islámské kultury trvalo od 9. do 14. století a ve srovnání s tehdejší křestanskou Evropou byl muslimský svět výrazně vojensky i vědecky pokročilejší. Ke kulturní změně a růstu vědeckého a technologického potenciálu v Evropě došlo v období renesance a humanismu. Západ se vydal cestou modernizace, zatímco islámská kultura uvízla v pasti tradicionalismu. Situaci, ve které se islám ocitl po 14. století, výstižně popsal americký islamista Bernard Lewis, jenž označil stagnaci muslimské vědy za „období bezčasí" - dobu, kdy se nic nemění (Lewis 1982). Islámští učenci, spoutaní doktrínou tradicionalismu, ztratili zájem o hledání nových poznatků a inovace, které se rodily za hranicemi islámu. Vědecké poznání v muslimských zemích bylo degradováno na „soubor věčných pravd, které musí být získávány, shromaždovány, předávány, vysvětlovány a používány, nikoliv pozměňovány“ (Hofstede - Hofstede 2007, 297). Dostatečně výmluvný je z tohoto hlediska postoj islámu k vynálezu knih- tisku. Ten byl v Evropě objeven okolo roku 1450 a relativně rychle začal být využíván jako efektivní nástroj šíření informací. Oproti tomu v islámském Turecku byl tiskařský lis poprvé instalován v roce 1729 , ale krátce poté v roce 1742 , na základě intervence konzervativních muslimů, byl jeho provoz zastaven " (Hofstede - Hofstede 2007, 178). Podle Bernarda Lewise byla ignorace Západu ze strany islámu zpơsobena tím, že muslimové primárně vnímali Evropu výhradně skrze prizma svého náboženství v náboženských pojmech. Z perspektivy islámu Evropa představovala území, kde vládlo pomýlené a zavrženíhodné křest̉anství, a proto i technologické inovace a vědecké poznání, které zde vznikaly, muslimské země ignorovaly (Lewis 1982, 168-229). Technologická, ekonomická a vojenská převaha Západu se v plném rozsahu projevila v průběhu 19. století, kdy Evropané osvobodili od Turků území na Balkáně a ovládli i tradiční arabská území v severní Africe, která se dostala do koloniálního područí Francie a Velké Británie.

Koloniální nadvláda měla pro islámskou kulturu katastrofální následky. Skutečnost, že islámské země nebyly schopny čelit expanzi Západu, ale ve svých důsledcích vedla ke vzniku reformních hnutí, která usilovala o obrodu islámu a upevnění muslimské kulturní identity. Ve druhé polovině 20. století došlo $\mathrm{k}$ výraznému nárůstu islámských náboženských i politických revitalizačních hnutí, včetně radikálního náboženského fundamentalismu. Významnou roli z tohoto hlediska sehrála zejména islámská revoluce, $\mathrm{k}$ níž došlo v Íránu v letech 1978-1979 a která prohlásila korán za základ veškerého politického a ekonomického života. Obnovené islámské právo („šaría“) zahrnuje soubor norem, jimiž by se měl pravověrný muslim a člen obce věřících řídit a dodržovat je ve světském i duchovním kontextu. V Íránu šarỉa představuje jádro sociokulturních regulativů a zásadním způsobem ovlivňuje činnost vlády, fungování společnosti i rodiny. Došlo k oddělení obou pohlaví, ženy musí na veřejnost vycházet zahaleny, cizoložství je trestáno ukamenováním, homosexualita zastřelením. Ideje islámské revoluce se rychle šírily do dalších arabských zemí, kde získaly značnou podporu a popularitu a stimulovaly nejrůznější formy obrody islámu $\mathrm{v}$ jiných arabských zemích. $\mathrm{V}$ řadě arabských států, které byly v určitém období poměrně demokratické, došlo v průběhu uplynulých 20 let $\mathrm{k}$ prŕklonu k radikálnímu islámu a islamizaci státu.

Ideologie islámské revoluce, nastolená v Iránu, usiluje o spojení islámského světa proti ekonomické, vojenské a politické hegemonii Západu. Paralelně s globalizací islámu ale v jeho rámci probíhá diferenciace různých směrů a frakcí, jako jsou neofundamentalismus, spiritualismus, salafismus a další. Muslimové totiž nevytvářejí jeden kompaktně uzavřený, centralizovaný, sociokulturní, etnický nebo národnostní celek a prríslušnost $\mathrm{k}$ islámu neznamená jednotný ideologický př́ístup. K základnímu ideovému rozštěpení islámu ostatně došlo již v jeho počátcích v 7. století, kdy se zformovala většinová větev sunnitů a menšinová odnož šíitů. V této souvislosti je nezbytné odlišit pojmem „islámský“, jehož význam se vztahuje k islámu, od pojmu „islamistický“, jehož význam je spojován s islamismem - souborným označením „širokého spektra 
ideologií a směrů, které mají společný právě a pouze odkaz na politické učení islámu“ (Souleimanov 2006). Islamismus je spojen se širokým spektrem náboženských a politických islamistických hnutí. Současná protizápadní argumentace islamistů je vedena jako přirozená politická reakce na expanzivní politiku Západu. Podle Gillese Kepela jedním ze společných znaků islamistické ideologie je, že islamistická ideologie, „at’ už má jakoukoliv podobu - umírněnou či radikální, konzervativní či revoluční, mírumilovnou či násilnou, nebo dokonce teroristickou -, se vychloubá svou autentičností a nezištností, svou výlučnou starostí o zájmy lidu, z něhož vyšla, a nikoli o zájmy zahraničních mocností či světového ropného trhu“ (Kepel 2006, 68).

Teroristický útok 11. záŕí 2001 na symboly ekonomické a vojenské moci Spojených států amerických - Světové obchodní centrum v New Yorku a Pentagon ve Washingtonu - zahájil novou etapu ve vztahu Západu a Orientu. Skutečnost, že útočníky byli příslušníci islámské extrémistické organizace alKáidá, vyvolala rozsáhlé diskuze na téma celosvětového střetu civilizací, který v 90. letech 20. století „předpověděl“ americký historik a politolog Samuel Huntington. „Den před“ se Amerika díky své geografické poloze, materiálním zdrojům, technologické a vojenské převaze cítila být nedotknutelnou „pevnosti“. „Den po“ teroristickém útoku si prostí američtí občané, vojenští odborníci i antropologové zabývající se studiem cizích kultur byli nuceni položit otázku, proč vlastně $\mathrm{k}$ této tragické události došlo. Spojené státy americké reagovaly dvěma mezinárodními vojenskými zásahy. První útok směřoval proti Afghánistánu, kde odstranil ústřední vládu Tálibánu. Druhý útok byl proveden proti Iráku a vedl k odstranění vlády Saddáma Husajna a následné krvavé okupaci země. Ani v Afghánistánu ani v Iráku se však okupačním armádám nepovedlo dostat situaci zcela pod kontrolu. V obou zemích i nadále probíhá ozbrojený odpor. V Afghánistánu v podobě partyzánské války, v Iráku především formou pumových útoků a atentátů na vojáky koalice. Pro civilní irácké obyvatelstvo jsou důsledky války zničující. Podle empirického průzkumu, který v roce 2007 mezi 2 tisíci Iráčany provedla rozhlasová a televizní stanice BBC, se $64 \%$ dotázaných nachází ve velmi špatné ekonomické situaci a $43 \%$ žije v absolutní bídě. Jako poněkud nebo velmi špatnou označili dostupnost elektřiny (88\%), paliva pro automobily (88\%), hygienických zařízení (80\%) a čisté vody (69\%). Zhoršující se sociální a ekonomické podmínky a špatná bezpečnostní situace způsobily, že $51 \%$ populace považuje útoky na síly koalice za akceptovatelné. Pro stále větší množství obyvatel arabských zemí je americká přítomnost v oblasti Předního východu nežádoucí. Mnohé nasvědčuje tomu, že Spojené státy americké učinily ve vztahu k arabským zemím řadu fatálních chyb a svým vojenským zásahem přispěly k eskalaci napětí mezi Východem a Západem. Jedním $\mathrm{z}$ negativních důsledků této situace je růst islamistického radikalismu, neofundamentalismu a teroristických útoků po celém světě.

Problém konfrontace islámské a křestanské kultury lze analyzovat z perspektivy historie a politologie. Samuel P. Huntington (narozen 1926) v knize Střet civilizací: Boj kultur a promě- na světového řádu (1996) odmítl teorii, že přičiny konfliktu Západu a Východu tkví v sociálně psychologických faktorech, jakými jsou např́iklad křestanské zanícení nebo muslimský fundamentalismus. Kořeny střetu křestanství s islámem mají podle jeho názoru svůj původ v odlišné podstatě obou náboženství a z nich vyrůstajících jiných typů civilizací. Muslimské pojetí islámu představuje způsob života, ve kterém je víra úzce spjatá s politikou. Oproti tomu západní křestanská tradice odděluje politickou moc od sféry vyhrazené Bohu. Slovy Huntingtona - v islámu se spojuje „hájemství Boha a císaře, oproti pojetí západokřestanskému, jež rísí Boží odděluje od ríše císařovy" (Huntington 2001, 250). Příčinou konfliktu je ovšem i jistá podobnost. Křestanství i islám jsou monoteistická náboženství, a proto nejsou schopny asimilovat jiná božstva. Na svět pohlížejí dualistickou optikou klasifikující svět v kategoriích „my“ a „oni“. Navíc jde o náboženství univerzalistická. Křestanství, stejně jako islám, usilují o to - být jedinou pravou vírou, ke které se může přiklonit celé lidstvo. V neposlední řadě se jedná o náboženství misionářská - věřící sdílejí přesvědčení, že jejich povinností je obracet na jejich víru nevěřící. Obě dvě náboženství a $z$ nich vyrůstající civilizace spojuje také skutečnost, že se šírily územními výboji. Válečná expanzívnost nalezla svůj výraz v analogických pojmech - „džihád“ a „kř́ižová výprava“. Na eskalaci násilných střetů mezi islámem a křestanstvím $\mathrm{v}$ dějinách měly svůj podíl také demografické, ekonomické a technologické faktory. Populační exploze v muslimských zemích, těžba a vývoz arabské ropy a proměny tradiční muslimské kultury pod tlakem modernizace a globalizace ve 20 . století oživily př́činy konfliktu mezi islámem a Západem. Zásadním problémem Západu však není islámský fundamentalismus. Jak konstatoval Huntington: „Je to islám, odlišná civilizace, jejiž př́slušníci jsou presvědčeni o nadřazenosti své kultury a posedlí slabostí své moci. Problémem islámu není CIA ani americké Ministerstvo obrany - je jím Západ, odlišná civilizace, jejiž příslušníci jsou přesvědčeni o univerzalitě své kultury a domnívají se, že jejich nadřazená, byt' upadající moc jim ukládá tuto kulturu šírit po celém světě (Huntington 2001, 250).

Muslimské země se ocitly v osudovém dilematu. Na jedné straně touží po ekonomické prosperitě a výhodách technicky vyspělé civilizace, na straně druhé se brání pronikání západních hodnot, idejí a institucí do islámského způsobu života. Jak v této souvislosti poznamenal americký politolog Francis Fukuyama (narozen 1952), problém islámských zemí spočívá v tom, že „modernost“ proniká do arabského světa jako „balík“ - komplexní celek zahrnující nejen žádoucí západní technologie, ale také odlišné kulturní hodnoty destruující tradiční islámský způsob života.

\section{ORIENTALISMUS ANEB DIALOG ZTRACENÝ V PŘEKLADU}

Historická a politologická analýza prř́čin „střetu civilizací může být rozšířena (nebo „dekonstruována“) o antropologicky koncipovanou postmoderní interpretaci daného pro- 
blému. Ta by mohla umožnit „aplikovaným“ antropologům, aspirujícím na řešení vztahu Západu a Východu, zaujmout zcela nový teoretický př́stup a formulovat novou strategii. Inspirativní postmoderní kulturální analýzu vztahu Západu (Okcident) a Východu (Orient) z tohoto hlediska originálním zpo̊sobem uplatnil palestinský literární kritik, působící ve Spojených státech amerických - Edward Wadie Said (1935-2003). Said se narodil v arabské rodině v Jeruzalémě v Palestině, ale emigroval do Spojených států amerických, kde studoval na Princetonské a Yaleské univerzitě. Od roku 1963 působil jako anglista a profesor srovnávací literatury na Columbia University v New Yorku. Said je společně s Homi K. Bhabhou (narozen 1949) a Gayatri Chakravortou Spivakovou (narozena 1942) považován za jednoho z hlavních představitelů postkoloniální literatury a postmoderní kulturní teorie. Publikoval řadu studií a knih věnovaných obecné literární teorii, anglické literatuře, interpretaci hudby, kritice médií a palestinské politice. Ve světě však nejvíce proslul svými pracemi o Blízkém východě a analýzou vztahu mezi Západem a Orientem, kterou v roce 1978 předložil v knize Orientalism: Western Conceptions of the Orient (česky: Orientalismus: Západní koncepce Orientu, 2008). Svůj koncept kritiky orientalismu dále rozpracoval ve studii Culture and Imperialism (Kultura a imperialismus, 1993), v níž rozšíril spektrum své analýzy také na mimoorientální kolonie na území černé Afriky, Indie, Austrálie a v Karibiku. Said zastával velmi kritický postoj k Izraeli, který obviňoval, že se chová vưči Arabům xenofobně. Když Jásir Arafat podepsal s Izraelem mírovou dohodu, obvinil jej, že kolaboruje s okupanty. V posledních letech svého života Said spolupracoval s izraelským hudebníkem Danielem Barenboimem, s nímž pořádal klavírní koncerty na západním břehu Jordánu a propagoval projekt společných koncertů arabských a izraelských muzikantů.

Said se ve své vlivné analýze vztahu západní civilizace a orientálních zemí inspiroval zejména úvahami francouzského filozofa Michela Foucaulta (1926-1984) o vztahu vědění a moci. Foucault byl přesvědčen, že společenské vědy nepředstavují nezaujaté disciplíny, ale diskurz - soubor názorů na společnost, které danou společnost a její představy o pravdě ovlivňují. Proto věnoval pozornost tomu, jak znalosti a na nich založený diskurz společnost využívá $\mathrm{k}$ fungování a reprodukci mocenských struktur. Diskurz není neutrálním médiem pro tvorbu a přenos hodnot, významů a vědění, ale prostřednictvím diskurzivních praktik tyto hodnoty, významy a vědění aktivně ustavuje. Slovy Foucaulta: „Žádný soubor poznání nelze vytvořit bez systému komunikací, záznamů, akumulace a nahrazování, který je sám o sobě formou moci a svou existencí a fungováním je spojen sostatnimi formami moci. A naopak, žádnou moc není možno vykonávat bez vyjmutí, privlastnění, distribuce a retence poznání. V této rovině neexistuje na jedné straně poznání a na druhé společnost - nebo věda a stát -, ale jenom fundamentální formy poznání/moci (...)“(Foucault 1980, 131).

Podle Saida je klíčem k pochopení nerovného vztahu Západu a Orientu kategorie „orientalismus“. Said tímto po- jmem neoznačuje pouze vědeckou a literární tradici spjatou se studiem a popisem orientálních zemí, ale upozorňuje na to, že produktem odborného a uměleckého zájmu Západu o Východ se stal orientalismus jako specifická kulturní konstrukce, vystupující v podobě zkresleného a stereotypizovaného obrazu Orientu, který vytvořili v koloniální éře západní odborníci na orientální kultury, historii, jazyky, filozofii a náboženství. Orientalismus z tohoto hlediska nepředstavuje pouze vědní disciplínu, ale širší diskurz v oblasti mocenských vztahů, který zahrnuje mnohem více než filologické, historické a antropologické poznatky. Je tvořen širokým spektrem textů věnovaných Orientu, včetně literárních děl, cestovních průvodců, novinářských zpráv, politických traktátů, prŕrodovědeckých studií a náboženských spisů, které vznikaly od 18. století především v Anglii a ve Francii a od druhé světové války ve Spojených státech amerických. Podle Saida Orient není jakýmsi neměnným faktem, nýbrž „představou s vlastní myšlenkovou, imaginativní a terminologickou historií a tradicí, která ji postupně utvárela a zpř́itomňovala pro oblast Západu"(Said 2008, 15). Said je přitom přesvědčen, že všechny západní texty a poznatky popisují, vysvětlují a objasňují Orient z pozice síly. Orientalismus je z této perspektivy „postupem, jímž Západ Orientu vládne, restrukturalizuje jej a spravuje" (Said 2008, 13). Je to diskurz moci zrcadlící politickou a ekonomickou hegemonii Západu. Slovy Saida: „Vztah mezi západní civilizací a Orientem je vztahem moci, dominance a různých stupñu hegemonie“ (Said 2008, 16). Tato konceptualizace Orientu je ovšem pouhou kulturní konstrukcí, která za pomoci heterogenní stereotypizace umožnila ideologicky, vědecky a imaginativně ovládnout a vytvářet obraz Východu. Podle Saida orientalismus představuje systém idejí a zobrazení prodchnutých evropskou nadřazeností, rasismem a imperialismem, které jsou vypracovány a šíreny rozmanitými texty a praktikami. Je to systém reprezentací, které přinášejí Orient do západní vzdělanosti. Mezi takové reprezentace patří například Flaubertův literární popis jeho setkání s egyptskou tanečnicí a kurtizánou Kučuk Hánim. Ta je prezentována jako smyslná, citově a sexuálně nevázaná orientální žena, jež nikdy nemluví za sebe, neprojevuje emoce a není schopna samostatně jednat. Způsob, jakým Gustave Flaubert vytvořil široce přijímaný „model orientální ženy“, odráží jeho dominantní pozici a ilustruje nerovné rozložení sil mezi Západem a Východem. Flaubert vystupoval v roli zámožného cizince mužského pohlaví a disponoval vlastnostmi a prostředky, aby si mohl dotyčnou „ženu nejen přivlastnit fyzicky, ale také za ni mluvit a sdělovat čtenářrum, v jakém ohledu byla typicky orientáni" (Said 2008, 16). Podobným způsobem se utvářel obraz orientálního muže, který je na Západě spojován se lstivostí, krutostí, fanatismem a despotismem.

Saidova teorie orientalismu naznačuje, že rasismus se utváří prostřednictvím vzorců kulturní reprezentace, které jsou hluboce zakořeněny $\mathrm{v}$ praktikách a diskurzních technikách západních společností. Orientalismus jako úhel pohledu rozdělil zeměkouli na Okcident a Orient a redukoval složitost východních kultur do zjednodušených kategorií zrca- 
dlících převahu Západu. Orientalismus představuje historicky vzniklou specifickou diskurzivní konstrukci, jejímž produktem jsou lživé typologie, ve kterých stojí proti sobě racionální, morální a vlídný západní člověk a mravně kluzký, nevypočitatelný a krutý orientálec. Na rozdíl od Západu byl Orient prezentován jako tajemný, senzuálně iracionální, odpudivě živočišný a potenciálně nebezpečný nebo brutální. Prostřednictvím orientalismu však bylo možné tento nesrozumitelný a exotický východní svět uchopit a porozumět mu z perspektivy západní kultury. Koloniální síla a moc tak nalezla své vyjádření ve vědě a v představě, ,že zatímco my obyvatele Orientu známe a mluvíme o nich, oni pořádnè neznají ani sami sebe, natož aby mluvili o nás"(Turner 1983, 31).

Pro aplikovanou antropologii, která programově aspiruje na využití antropologického poznání pro dosažení žádoucí kulturní změny, znamená Saidova koncepce orientalismu zásadní výzvu. Zamyslíme-li se totiž nad problémem střetu civilizací z perspektivy orientalismu jako diskurzu moci, je zřejmé, že k optimalizaci vztahu mezi Západem a Východem nestačí nastolit rovnoprávnost $\mathrm{v}$ oblasti politických a ekonomických vztahů. Neméně důležitá je dekonstrukce kulturního diskurzu orientalismu, který v sobě odráží tradiční koloniální a postkoloniální nerovnost. V současné západní kultuře tradiční koncept orientalismu bohužel nejenže přetrvává, ale je posilován prostřednictvím médií, $\mathrm{z}$ nichž některá povýšila islám do role hlavního strašáka západního zpravodajství. V centru zájmu západních televizních a rozhlasových zpravodajství je prezentace konfliktů na Blízkém východě v kontextu světového terorismu a iracionálního náboženského fanatismu. V kulturní reprezentaci islámu na Západě se média soustředují na násilné činy některých islámských fundamentalistů, ale podstatně menši pozornost věnují přičinám neprátelství Orientu vůči Západu a podílu západní politiky a ekonomiky na prohlubování konfliktů na Blízkém východě. Př́iliš často se západní diváci, čtenáři a posluchači ani nedovědí, že islám považuje většina jeho stoupenců za filozofii a náboženství lásky, míru a spolupráce.

Saidovy práce výrazně stimulovaly antropologické úvahy na téma ,jak si jedna kultura představuje druhou“. S ohlasem Saidových myšlenek se můžeme setkat $\mathrm{v}$ dílech Bernarda S. Cohna, Davida Lorenzena, Carol Breckenridgeové, Ronalda Indena a dalších. Ǩada antropologů a sociologů ovšem upozornila na skutečnost, že kategorie orientalismu vyžaduje zavedení komplementárního pojmu, který by reflektoval „obraz Západu“. Stejně jako si Západ prostřednictvím orientalismu vytvořil falešnou představu Východu, západní učenci i cizinci konstruují zkreslenou a stereotypní prredstavu Západu. Jako párová kategorie $\mathrm{k}$ orientalismu se tak zrodil „okcidentalismus“, obraz Západu tak, jak jej utvárí a sdílejí lidé uvnitř i vně západní společnosti. Při rozpracování teorie okcidentalismu sehrál významnou roli sborník prací Okcidentalismus editovaný Jamsem Carrierem (Carrier 1995). O aktuálnosti studia okcidentalismu jako kulturní konstrukce a stereotypizovaného obrazu Západu svědčí reakce muslimů na teroristické útoky provedené 11. září proti Spojeným státům americkým. Přestože většina muslimů tyto útoky odsuzuje, následnou odvetu v Afghánistánu nepovažuje za adekvátní. Navzdory prokázaným faktům velmi málo lidí v islámském světě věří, že unesená letadla navedli na New York a Washington Arabové. Podíl na negativním hodnocení kroků, které na svoji obranu provedli Američané, má „obraz Spojených států amerických“ sdílený většinou muslimů. Podle rozsáhlého výzkumu realizovaného Gallupovým institutem v Saúdské Arábii, Íránu, Pákistánu, Indonésii, Turecku, Libanonu, Kuvajtu, Jordánsku a Maroku jsou totiž Spojené státy americké považovány za bezcitnou, nafoukanou, arogantní a zaujatou zemi. Na utváření obrazu Spojených států amerických mají významný podíl samotní Američané a jejich specifický vztah $\mathrm{k}$ historii a geografickému prostoru, který v knize The Idea of Culture (2000, česky: Idea kultury, 2001) výstižně popsal Terry Eagleton: „Jestliže Američané nemají velké vazby $k$ historii, mají daleko i $k z e$ měpisu, což je předmět, $v$ němž zpravidla neprospivají. Spojené státy, jež patří k nejprovinčnějš́m společnostem na světě, jsou vlastně odřiznuty od všeho kromě Kanady (která je př́liš stejná) a Latinské Ameriky (která je hrozivě odlišná) a maji až překvapivě malé ponětí o tom, jak pưsobí zvenčí. Jestliže se $v$ jejich ulicích spokojeně promenáduji až surreálnè tlustí lidé, je to zpưsobeno také tím, že vůbec nevědí, že jinde to tak nechodí. Američané navíc používají slovo ,Amerika 'mnohem častěji nežli Dánové slovo ,Dánsko nebo Malajci slovo,Malajsie. Pro zemi, která se na okolní svět dívá většinou pouze objektivem kamery nebo $z$ bombardéru, je to typické" (Eagleton 2001, 104-105)

Analýza stereotypů sloužících $\mathrm{k}$ prezentaci vlastní a interpretaci cizí společnosti a kultury, představuje významný tematický okruh současné vědy o kultuře. Je pravděpodobné, že zájem o analýzu kulturních konstrukcí „orientalismus“ versus „okcidentalismus“ bude narůstat nejen v souvislosti se střetem kultur, ale také při výzkumu procesů ekonomické integrace světa. Zamyslíme-li se nad budoucností vědy o kultuře ve světě, který je na jedné straně diferencován střetem kultur, na straně druhé integrován procesy modernizace a globalizace, nemusíme mít obavu, že antropologie ztratí své opodstatnění. Aplikované antropologii lze tedy vytyčit relativně významný úkol - výzkum transkulturní komunikace, který umožní rozhovor mezi př́slušníky různých etnik, kultur a subkultur. Jak konstatoval Clifford Geertz, bude to především antropologie, jež zvýší možnost „srozumitelné diskuse mezi lidmi, kteři se vzájemně liši v zájmech, názorech, bohatství a moci, a přece žijí ve světě, kde - strženi v nekonečné spojení - je stále obtižnějši jít si vzájemně z cesty" (Geertz 1988, 147). A právě jednou $z$ cest umožňujících nastolit konstruktivní dialog mezi Západem a Východem by mohla být dekonstrukce tradičního obrazu Orientu, založeného na diskurzu moci. To ovšem ve svých důsledcích vyžaduje komplexně přehodnotit vztah poznání a moci. Pokud západní věda tento krok neučiní, hrozí, že dialog mezi Západem a Východem bude navždy ztracen. Ztracen v kulturním překladu ... 


\section{LITERATURA}

Bible: Písmo svaté Starého a Nového zákona (1979). Praha: Ústřední církevní nakladatelství.

Campbell, Joseph (1988): Myths to Live by. New York: Bantam Books.

Carrier, James G., ed. (1995): Occidentalism: Images of the West. Oxford: Oxford University Press.

Eagleton, Terry (2001): Idea kultury. Brno: Host.

Geertz, Clifford (1988): Work and Lives: The Anthropologists as Author. Stanford: Stanford University Press.

Hofstede, Geert - Hofstede, Gert Jan (2007): Kultury a organizace: Software lidské mysli. Praha: Linde.

Huntington, Samuel P. (2001): Střet civilizací: Boj kultur a proměna světového rádu. Praha: Rybka Publisher.

Kepel, Gilles (2006): Válka v srdci islámu. Praha: Karolinum.

Lewis, Bernard (1982): The Muslim Discovery of Europe. London: Weidenfield and Nicholson.

Said, Edward W. (2008): Orientalismus: Západní koncepce Orientu. Paseka, Praha - Litomyšl: Paseka.

Said, Edward W. (1993): Culture and Imperialism. New York: Alfred A. Knopf.
Souleimanov, Emil, ed. (2006): Terorismus, válka proti státu. Praha: Eurolex Bohemia.

Turner, Bryan S. (1983): Religion and Social Theory: A Materialist Perspective. London: Heinemann Educational Books.

\section{AUTOR}

Soukup, Václav (31. 8. 1957, Mariánské Lázně), český kulturolog a antropolog, vedoucí Katedry teorie kultury na Filozofické fakultě Univerzity Karlovy v Praze, kde přednáší základy sociální a kulturní antropologie, kulturologie a paleoantropologie. Patří k zakladatelům interdisciplinárně koncipovaného studijního oboru kulturologie a průkopníkům biokulturologie. Své názory na předmět, metody a dějiny antropologie shrnul v knihách Déjiny antropologie (2004) a Antropologie: teorie člověka a kultury (2011).

Kontakt: Kontakt: PhDr. Václav Soukup, CSc., Katedra teorie kultury (kulturologie) Filozofické fakulty Univerzity Karlovy v Praze, Celetná 20, 11000 Praha 1, e-mail: Vaclav.Soukup@ff.cuni.cz. 